\title{
Analysis of the Gastrin-Releasing Peptide Receptor Gene in Italian Patients With Autism Spectrum Disorders
}

\author{
G. Seidita, ${ }^{1}$ M. Mirisola, ${ }^{1}$ R.P. D’Anna, ${ }^{1}$ A. Gallo, ${ }^{1}$ R.T. Jensen, ${ }^{2}$ S.A. Mantey, ${ }^{2}$ N. Gonzalez, ${ }^{2}$ M. Falco, ${ }^{3}$ \\ M. Zingale, ${ }^{3}$ M. Elia, ${ }^{3}$ L. Cucina, ${ }^{3}$ V. Chiavetta, ${ }^{3}$ V. Romano, ${ }^{4 *}$ and F. Cali ${ }^{3}$ \\ ${ }^{1}$ Dipartimento di Biopatologia e Metodologie Biomediche, Università degli Studi di Palermo, Palermo, Italy \\ ${ }^{2}$ Digestive Diseases Branch, National Institutes of Health, Bethesda, Maryland \\ ${ }^{3}$ Associazione OASI Maria SS (I.R.C.C.S.), Troina (EN), Italy \\ ${ }^{4}$ Dipartimento di Oncologia Sperimentale e Applicazioni Cliniche, Università degli Studi di Palermo, Palermo, Italy
}

The gastrin-releasing peptide receptor (GRPR) was implicated for the first time in the pathogenesis of Autism spectrum disorders (ASD) by Ishikawa-Brush et al. [Ishikawa-Brush et al. (1997): Hum Mol Genet 6: 1241-1250]. Since this original observation, only one association study [Marui et al. (2004): Brain Dev 26: 5-7] has further investigated, though unsuccessfully, the involvement of the GRPR gene in ASD. With the aim of contributing further information to this topic we have sequenced the entire coding region and the intron/exon junctions of the GRPR gene in 149 Italian autistic patients. The results of this study led to the identification of four novel point mutations, two of which, that is, C6S and L181F, involve amino acid changes identified in two patients with ASD and Rett syndrome, respectively. Both the leucine at position 181 and the cysteine at position 6 are strongly conserved in vertebrates. C6S and $\mathrm{L181F}$ mutant proteins were expressed in COS-7 and BALB/3T3 cells, but they did not affect either GRP's binding affinity or its potency for stimulating phospholipase Cmediated production of inositol 1,4,5-trisphosphate. In summary, our results do not provide support for a major role of the GRPR gene in ASD in the population of patients we have studied. However, there is a potential role of $\mathrm{C6S}$ and L181F mutations on GRPR function, and possibly in the pathogenesis of the autistic disorders in the two patients. (c) 2008 Wiley-Liss, Inc.

KEY WORDS: autism; gastrin-releasing peptide receptor; signal transduction; Gprotein-coupled receptor; association study

Please cite this article as follows: Seidita G, Mirisola M, D'Anna RP, Gallo A, Jensen RT, Mantey SA, Gonzalez N, Falco M, Zingale M, Elia M, Cucina L, Chiavetta V,

This article contains supplementary material, which may be viewed at the American Journal of Medical Genetics website at http://www.interscience.wiley.com/jpages/1552-4841/suppmat/ index.html.

*Correspondence to: V. Romano, Dipartimento di Oncologia Sperimentale e Applicazioni Cliniche, Università degli Studi di Palermo, via San Lorenzo Colli, 312-90146 Palermo, Italy. E-mail: vromano@unipa.it

Received 6 May 2007; Accepted 14 February 2008

DOI 10.1002/ajmg.b.30752
Romano V, Cali F. 2008. Analysis of the GastrinReleasing Peptide Receptor Gene in Italian Patients With Autism Spectrum Disorders. Am J Med Genet Part B 147B:807-813.

\section{INTRODUCTION}

Autism spectrum disorders (ASD; OMIM \#209850) are developmental disorders with complex phenotypes defined by a triad of symptoms that include impaired social abilities, deficient verbal and non-verbal communication skills, and restricted interests with repetitive behaviors [APA, 2000]. The underlying etiology remains largely unknown, yet ASD is one of the most highly heritable of neuropsychiatric disorders [Kates et al., 2004]. However, in only $10 \%$ of these patients has a defined genetic disorder, either chromosomal or monogenic [see Persico and Bourgeron, 2006 for a review], or a teratogen, been identified as a likely etiological factor. Among monogenic disorders, Rett syndrome (RTT; OMIM 312750) shares overlapping clinical features with autism, and clinical assessments of social behavior have demonstrated a high frequency of autism in Rett syndrome patients [Gillberg, 1986]. Rett syndrome is an X-linked dominant neurodevelopmental disorder very often caused by mutations in the MECP2 gene [Bienvenu et al., 2000] which encodes the methyl-CpG-binding protein 2 (MeCP2). $M E C P 2$ mutations have also been found in a few patients diagnosed with autism [Carney et al., 2003] suggesting overlap also in the pathogenesis of these two distinct genetic syndromes.

The gastrin-releasing peptide receptor (GRPR; chromosomal location: Xp22.3-p21.2) is a member of the G protein-coupled receptor superfamily containing seven transmembrane domains. Gastrin-releasing peptide (GRP) binds to GRPR to elicit a broad spectrum of biological effects on behavior, digestion, and metabolism [see Roesler et al., 2006 for a recent review]. Studies evaluating the role of GRPR in behavior and synaptic plasticity in rodents indicate that GRPR's in brain limbic areas such as the amygdala and hippocampus are involved in behaviors related to emotional responses, fear related learning, stereotypy and social interaction [Shumyatsky et al., 2002]. Because the latter phenotypes are all features of autism, the findings from rodent models also support the view that the GRPR might be involved in the pathogenesis of autism. Ten years ago the GRPR gene was proposed as a candidate locus for infantile autism by Ishikawa-Brush et al. [1997]. These authors detected an X-8 translocation, occurring in the first intron of the GRPR gene, in a female patient with multiple exostoses and autism accompanied by mental retardation and epilepsy. A subsequent study performed in Japanese patients by Marui et al. [2004] failed to detect association of ASD with intragenic polymorphisms of the GRPR gene. Surprisingly, with the exception of an additional study [Heidary et al., 1998] who excluded the GRPR gene as a 
candidate locus for Rett syndrome, no other molecular genetic studies have scanned the GRPR gene to search for mutations potentially implicated in ASD. In this article we describe the results of: (i) sequence analysis of the GRPR gene performed in a cohort of 149 autistic patients (ii) the functional in vitro expression analysis of two missense mutations identified in two patients diagnosed, respectively, with ASD and RTT and (iii) an association study carried out with intragenic polymorphisms.

\section{PATIENTS AND METHODS}

\section{Patients}

All patients (133 males and 16 females accounting for a male/ female ratio of $8.31: 1$, mean age 14.63 years; $S D \pm 5.85$ years) are mentally retarded and met DSM-IV-TR criteria [APA, 2000] for an autistic disorder. In addition, patients were assessed by means of the (i) Childhood Autism Rating Scale [CARS: Schopler and Dalldorf, 1980], (ii) Brunet-Lezine test [Brunet and Lézine, 1966], (iii) WISC-R test [Wechsler, 1974], (iv) Psychoeducational Profile Revised (PEP-R) [Schopler et al., 1990], (v) Griffith's Mental Developmental Scales [Griffiths, 1986], and (vi) Leiter International Performance Scale [Leiter, 1979]. Patient A49 was also assessed by the Vineland Adaptive Behaviour Scale [VABS: Sparrow et al., 1984]. The two affected brothers of family A71 (A71A and $\mathrm{A71B}$ ), were also assessed by the Autism Diagnostic Interview-Revised [ADI-R: Rutter et al., 2003], Autism Diagnostic Observation Schedule-Generic [ADOS-G: Lord et al., 2002] and by the Vineland Adaptive Behaviour Scale. ADI-R and ADOS-G could be administered to a limited number of patients because the, Author-approved, Italian versions of these interviews were available less than 2 years ago.

Patients were excluded from this study if they displayed at least one item from the following checklist: neurological focal signs, chromosomal abnormalities detected by conventional karyotyping, FMR1 gene mutation (fragile $\mathrm{X}$ syndrome), and other neurological diseases such as phenylketonuria, neurofibromatosis, tuberous sclerosis, encephalopathies due to congenital infections, abnormal plasma and urine aminoacids or abnormal urine mucopolysaccharides. Sicilian ancestry for $>95 \%$ of all patients was ascertained, for at least two generations, by enquiring about the place of birth of their maternal and paternal grandparents. Informed consent was obtained from patients' parents.

\section{DNA Isolation and PCR Amplification of the GRPR Gene Exons}

Genomic DNA was isolated from peripheral blood lymphocytes according to standard procedures. Primer pairs, the sequences of which are reported in supplementary Table IV, were designed to amplify: (i) the coding region of exon 1 , (ii) the coding region and corresponding exon/intron junctions of exon 2 and (iii) the coding region of exon 3 of the GRPR gene. All PCR reactions were performed in a $30 \mu \mathrm{l}$ reaction volume containing: $75 \mathrm{ng}$ of genomic DNA, $1 \mathrm{U}$ of Taq Polymerase $\left(\mathrm{GoTaq}^{\mathrm{R}}\right.$ Promega, Madison, WI), $20 \mathrm{pmol}$ of each primer, $0.2 \mathrm{mM}$ of each dNTP, $6 \mu$ l of a 5 X Colorless GoTaq ${ }^{\circledR}$ Reaction Buffer $\left(\right.$ GoTaq ${ }^{\circledR}$ Promega). PCRs were run for 30 cycles, each cycle performed as follows: $94^{\circ} \mathrm{C}$ for $30 \mathrm{sec}, 59^{\circ} \mathrm{C}$ for $30 \mathrm{sec}$, and $72^{\circ} \mathrm{C}$ for $45 \mathrm{sec}$. The reactions were terminated after an extension step at $72^{\circ} \mathrm{C}$ for 5 min.

\section{Site-Directed Mutagenesis}

The pcDNA3.1_hGRPR plasmid contains the full-length coding sequence of the GRPR gene. This plasmid was used to generate a modified version of the GRPR cDNA containing the sequence 5'-GACUACAAGGACGACGAUGACAAG- $3^{\prime}$ which encodes a FLAG epitope inserted between the last coding triplet and the stop codon. This epitope was expressed at the carboxy terminal end in the GRPR protein to be used as a tag for antibody reaction. This modification was performed by the QuikChange ${ }^{\circledR}$ II Site-Directed Mutagenesis Kits (Stratagene, La Jolla, CA) using primers MFLAGF and MFLAGR (see Supplementary Fig. 3b). The resulting plasmid was named pGRPR. Mutagenesis on the pGRPR plasmid, performed by the protocol described above, was also used to generate: (i) plasmid pGRPR C6S containing mutation c.17G $>\mathrm{C} \quad(\mathrm{C} 6 \mathrm{~S})$ and (ii) plasmid pGRPR_L181F containing mutation c.541C $>\mathrm{T}$ (L181F). The forward (F) and reverse (R) primers used to introduce the missense mutations are M6F/M6R (C6S) and M181F/M181R (L181F), their sequences are given in Supplementary Figure 3b.

\section{DNA Sequencing}

All DNA samples were sequenced bidirectionally using the ABI Prism Big Dye Terminator Cycle Sequencing Ready Reaction Kit (vers. 1.1) and the ABI 310 Genetic analyzer (Applied Biosystems, Foster City, CA). DNA fragments amplified from genomic DNA were purified using Exonuclease I and Shrimp Alkaline Phosphatase according to the manufacturer's protocol (Exo-SAP kit Amersham Biosciences, Uppsala, Sweden). Specific nested primers were used to sequence the GRPR gene (named by the suffix "seq" in Supplementary Table IV). Successful mutagenesis was checked by priming the sequence reaction with oligonucleotides complementary to the "T7 promoter primer" and "BGH reverse primer" sequences flanking the pcDNA3.1 polylinker (primers sequences available at the Invitrogen, Carlsbad, CA, website).

\section{In Silico Analysis}

Comparison of the human GRPR protein sequence to the orthologous sequence in other species was performed by the TBLASTN software vers. 2.2.10 available at http://www.ncbi. nih.gov/blast/ [Karlin and Altschul, 1990; Altschul et al., 1997].

\section{Functional Analyses of wt and Mutant GRPR Expressed in BALB 3T3 and COS-7 Cells}

The following cells and materials were obtained from the sources indicated: BALB 3T3 (mouse fibroblast) and COS-7 (monkey kidney) were from American Type Culture Collection (ATCC; Manassas, VA); Dulbecco's minimum essential medium (DMEM), phosphate-buffered saline (PBS), Roswell Park Memorial Institute (RPMI-1640), trypsin-EDTA and fetal bovine serum (FBS), G418 sulfate from Life Technologies, Inc. (Grand Island, NY); $\mathrm{Na}^{125} \mathrm{I}(2,200 \mathrm{Ci} / \mathrm{mmol})$ and myo$\left[2-{ }^{3} \mathrm{H}\right]$ Inositol $(20 \mathrm{Ci} / \mathrm{mmol})$ were from Amersham Pharmacia Bioscience, Amersham Place, UK; formic acid, ammonium formate, disodium tetraborate, soybean trypsin inhibitor, bacitracin, and AG1-X8 resin from Bio-Rad (Richmond, CA); $\left[\mathrm{Tyr}^{4}\right]$ bombesin $\left(\left[\mathrm{Tyr}^{4}\right] \mathrm{Bn}\right)$ and GRP were from Bachem (Torrance, CA); and bovine serum albumin (BSA) from ICN Pharmaceutical, Inc. (Aurora, $\mathrm{OH}$ ).

BALB 3T3 or COS-7 cells were transfected with the wildtype pGRPR or its mutants, pGRPR_C6S or pGRPR_L181F DNA using the transfecting agent Fugene 6, and incubated for $24 \mathrm{hr}$ at $37^{\circ} \mathrm{C}$ in a $5 \% \mathrm{CO}_{2}$ atmosphere. The cells were grown in Dulbecco's Modified Eagle's cell medium (DMEM) supplemented with $10 \%$ FBS.

The ${ }^{125} I-\left[D T y r^{6}, \beta A l a^{11}, P h e^{13}, N l e^{14}\right] B n(6-14)$ radioligand, with specific activity of $2,200 \mathrm{Ci} / \mathrm{mmol}$, was prepared as previously described [Mantey et al., 1997; Ryan et al., 1998]. Briefly, $0.8 \mu \mathrm{g}$ of IOD-GEN solution $(0.01 \mu \mathrm{g} / \mu \mathrm{l}$ in chloroform) was added to a $5 \mathrm{ml}$ plastic test tube, dried under nitrogen, and washed with $100 \mu \mathrm{l}$ of $0.5 \mathrm{M}$ potassium phosphate solution ( $\mathrm{pH}$ 7.4). To this tube $20 \mu \mathrm{l}$ of potassium phosphate solution 
(pH 7.4), $8 \mu \mathrm{g}$ of peptide in $4 \mu \mathrm{l}$ of water, $2 \mathrm{mCi}(20 \mu \mathrm{l})$ of $\mathrm{Na}^{125} \mathrm{I}$ were added and incubated for $6 \mathrm{~min}$ at room temperature. The incubation was stopped with $300 \mu \mathrm{l}$ of water. The radiolabeled peptide was separated using a Sep-Pak (Waters Associates, Milford, MA) and further purified by reverse-phase high performance liquid chromatography on a C18 column. The fractions with the highest radioactivity and binding were neutralized with $0.2 \mathrm{M}$ Tris buffer ( $\mathrm{pH} 9.5$ ) and stored with $0.5 \%$ bovine serum albumin $(\mathrm{w} / \mathrm{v})$ at $-20^{\circ} \mathrm{C}$.

Binding of ${ }^{125} \mathrm{I}$-Labeled $B N$-related peptides was performed as described previously [Mantey et al., 1993, 1997]. The standard binding buffer contained $24.5 \mathrm{mM}$ HEPES ( $\mathrm{pH} 7.4$ ), $98 \mathrm{mM} \mathrm{NaCl} 6 \mathrm{mM} \mathrm{KCl}, 5 \mathrm{mM} \mathrm{MgCl}_{2}, 2.5 \mathrm{mM} \mathrm{NaH}_{2} \mathrm{PO}_{4}, 5 \mathrm{mM}$ sodium pyruvate, $5 \mathrm{mM}$ sodium fumarate, $0.01 \%(\mathrm{w} / \mathrm{v})$ soybean trypsin inhibitor, $1 \%$ amino acid mixture, $0.2 \%(\mathrm{w} / \mathrm{v})$ bovine serum albumin, and $0.05 \%$ (w/v) bacitracin. BALB 3T3 or COS7 cells transfected with the wild-type pGRPR or its mutants, pGRPR_C6S or pGRPR_L181F were harvested, resuspended $\left(0.4 \times 1 \overline{0}^{6} / \mathrm{ml}\right)$ in standard binding buffer and incubated at $22^{\circ} \mathrm{C}$ for $60 \mathrm{~min}$ with $50 \mathrm{pM}{ }^{125} \mathrm{I}$-labeled ligand $(2,200 \mathrm{Ci} / \mathrm{mol})$ and varying concentrations of GRP. Aliquots $(100 \mu \mathrm{l})$ were removed and centrifuged through $300 \mu \mathrm{l}$ of incubation buffer in $400 \mu \mathrm{l}$ microfuge tubes at $10,000 \mathrm{~g}$ for 1 min using a Beckman Microcentrifuge $B$. The pellets were washed twice with buffer and counted for radioactivity in a gamma counter. The nonsaturable binding was the amount of radioactivity associated with cells in incubations containing $50 \mathrm{pM}$ radioligand $(2,200 \mathrm{Ci} / \mathrm{mmol})$ and $1 \mu \mathrm{M}$ unlabeled ligand. Non-saturable binding was $<10 \%$ of total binding in all the experiments. Receptor affinities were determined using the KaleidaGraph software (SynergySoftware, Reading, PA).

Measurement of $\left[{ }^{3} \boldsymbol{H}\right] \boldsymbol{I P}$. Changes in total $\left[{ }^{3} \mathrm{H}\right]$ inositol phosphates $\left(\left[{ }^{3} \mathrm{H}\right] \mathrm{IP}\right)$ in cells transfected with the hGRPR or its mutants were measured as described previously [Benya et al., 1994; Schumann et al., 2003]. Briefly, COS-7 cells transfected with the wild-type pGRPR or its mutants, pGRPR_C6S or pGRPR L181F were sub-cultured into 24-well plates $\left(5 \times 10^{4}\right.$ cell $\mathrm{s} /$ well $)$ in regular propagation media and then incubated for $24 \mathrm{hr}$ at $37^{\circ} \mathrm{C}$ in a $5 \% \mathrm{CO}_{2}$ atmosphere. The cells were then incubated with $3 \mathrm{Ci} / \mathrm{ml}$ of myo- $\left[2-{ }^{3} \mathrm{H}\right]$ inositol in growth medium supplemented with $2 \%$ FBS for an additional $24 \mathrm{hr}$. Before assay, the cells in the 24 -well plates were washed by incubating for $30 \mathrm{~min}$ at $37^{\circ} \mathrm{C}$ with $1 \mathrm{ml} /$ well of PBS ( $\mathrm{pH} \mathrm{7.0)}$ containing $20 \mathrm{mM}$ lithium chloride. The wash buffer was aspirated and replaced with $500 \mu \mathrm{l}$ of IP assay buffer containing $135 \mathrm{mM}$ sodium chloride, $20 \mathrm{mM}$ HEPES (pH 7.4), $2 \mathrm{mM}$ calcium chloride, $1.2 \mathrm{mM}$ magnesium sulfate, $1 \mathrm{mM}$ EGTA, $20 \mathrm{mM}$ lithium chloride, $11.1 \mathrm{mM}$ glucose, $0.05 \%$ BSA (w/v) and incubated with or without GRP, at concentrations between $1 \mathrm{pM}$ and $1 \mu \mathrm{M}$. After $60 \mathrm{~min}$ of incubation at $37^{\circ} \mathrm{C}$, the experiments were terminated by the addition of $1 \mathrm{ml}$ of ice cold $1 \%(\mathrm{v} / \mathrm{v})$ hydrochloric acid in methanol. Total $\left[{ }^{3} \mathrm{H}\right] \mathrm{IP}$ was isolated by anion exchange chromatography as described previously [Benya et al., 1994; Schumann et al., 2003]. Briefly, samples were loaded onto Dowex AG1-X8 anion exchange resin columns, washed with $5 \mathrm{ml}$ of distilled water to remove free $\left[{ }^{3} \mathrm{H}\right]$ inositol, then washed with $2 \mathrm{ml}$ of $5 \mathrm{mM}$ disodium tetraborate $/ 60 \mathrm{mM}$ sodium formate solution to remove $\left[{ }^{3} \mathrm{H}\right]$ glycerophosphorylinositol. Two milliliters of $1 \mathrm{mM}$ ammonium formate $/ 100 \mathrm{mM}$ formic acid solution were added to the columns to elute total $\left[{ }^{3} \mathrm{H}\right] \mathrm{IP}$. Each eluate was mixed with scintillation cocktail and measured for radioactivity in a scintillation counter. Receptor potencies $\left(\mathrm{EC}_{50}\right.$ 's) were determined using a KaleidaGraph curve-fitting program.

\section{Association Study}

The frequency of mutations c.453C $>\mathrm{T}$ and c.663C $>\mathrm{T}$ and derived haplotypes was compared between 149 autistic patients (133 males and 16 females) and a sample of 106 "non-autistic" male individuals (reference population) living in the same geographic area (Sicily) to verify the hypothesis of a genetic heterogeneity between "cases" and "controls." The group of 106 control males had a mean age of 55.53 years ( $\mathrm{SD} \pm 16.96)$ and belong to the general population living in the island of Sicily. Sicilian ancestry was ascertained for all individuals of this reference population as described above for the patients. Additional information on this reference population can be found in Romano et al. [2003].

\section{Statistical Analyses}

The receptor affinities and potencies for the native GRPR and mutant receptors were determined from the doseresponse curves using the least-squared, curve-fitting program KaleidaGraph (SynergySoftware). Affinities and potencies of the various receptors for a given agonist were compared using the Mann-Whitney $U$-test and values which differed by $P<0.05$ were considered significant and reported. All affinities and potencies are reported as means \pm SEM.

For the association study, the comparison between the frequencies of the GRPR gene single nucleotide polymorphisms (SNPs) and corresponding haplotypes was performed by the Chi-square test.

\section{RESULTS}

\section{Case Reports for Patients A71A, A71B, and A49}

Patient A71A is a 24-year-old male, the second born of nonconsanguineous parents. He has a brother affected by mental retardation and an autistic disorder (A71B). At 18 months of age he began to present social withdrawal and communication impairment. A diagnosis of autistic disorder was made at the age of 5 years. He came to our observation when he was 20 years old and at that time his cognitive and behavioral phenotypes were reassessed. Cognitive test (LIPS) and adaptive test (VABS) showed a severe mental retardation. IQ according to LIPS is $<30$ and adaptive level expressed as Age Equivalent, is 3.1. CARS scale gave a total score of 42.5. The ADI-R and ADOS-G scores (see Table I) confirm the diagnosis of $\mathrm{AD}$ in agreement with CARS and DSM-IV-TR criteria.

Patient A71B, the younger brother of A71A, is an 18-year-old male. His psychomotor development was normal until the age of 1 year, when an impairment in social interaction was observed for the first time. At 1 year of age he also presented with frequent stereotyped movements and hyperactivity.

Language development was reported as almost normal until 12 months of age, then it regressed. He came to our observation

TABLE I. ADI-R and ADOS-G Scores for A71A and A71B Patient's

\begin{tabular}{lccc}
\hline & $\begin{array}{c}\text { Autism } \\
\text { cut-off }\end{array}$ & $\begin{array}{c}\text { A71B } \\
\text { score }\end{array}$ & $\begin{array}{c}\text { A71A } \\
\text { score }\end{array}$ \\
\hline $\begin{array}{l}\text { ADI-R } \\
\quad \begin{array}{l}\text { Social impairment } \\
\text { (SI) }\end{array}\end{array}$ & 10 & 23 & 23 \\
$\begin{array}{l}\text { Communication } \\
\text { (CO) }\end{array}$ & 8 & 18 & 20 \\
$\begin{array}{l}\text { Repetitive behavior } \\
\text { (RB) }\end{array}$ & 3 & 6 & 6 \\
$\begin{array}{l}\text { ADOS } \\
\text { Communication }\end{array}$ & 4 & 9 & \\
$\quad(C O)$ \\
$\begin{array}{l}\text { Reciprocal social } \\
\text { interaction (RSI) }\end{array}$ & 7 & 12 & 10 \\
RSI + CO & 12 & 21 & 14 \\
\hline
\end{tabular}


at the age of 14 years. Cognitive test (LIPS) and adaptive test (VABS) showed a severe mental retardation. According to Leiter scale, IQ is $<30$ and adaptive behavior composite, expressed as Age Equivalent, is 2.1. CARS scale gave a total score of 43.5. The ADI-R and ADOS-G scores confirmed the diagnosis of $\mathrm{AD}$ in agreement with CARS and DSM-IV-TR criteria (see Table I). The patient displays self-injuring behavior and trichotillomania.

Patient A49 is a 26-year-old female of non-consanguineous parents. There is no family history of mental retardation, autistic disorder or Rett syndrome. She has a younger healthy brother. The patient came for the first time to our observation at the age of 6 years. This patient was initially diagnosed with autistic disorder and profound mental retardation according to the criteria of DSM-IV-TR. The lack of significant improvements of cognitive and adaptive performances even after several years of a training program and a reassessment of the behavioral phenotype strongly suggested a diagnosis of Rett syndrome. This latter diagnosis was then confirmed by the analysis of the MECP2 gene (see next paragraph).

\section{Mutation Analysis of the GRPR and MECP2 Genes}

The sequence analysis of the GRPR gene performed in 149 autistic patients overall uncovered six nucleotide changes all within the coding region. In exon 2 mutation c. $541 \mathrm{C}>\mathrm{T}$ leading to the missense mutation $\mathrm{L} 181 \mathrm{~F}$ was detected in a heterozygote girl (Patient \#A49) affected by Rett syndrome. The analysis of the MECP2 gene in this patient indeed confirmed she was heterozygote for the de novo mutation R306C (see Fig. 1a). In an autistic boy (A71B) mutation c. $17 \mathrm{G}>\mathrm{C}$ in exon 1 leading to the missense mutation $\mathrm{C} 6 \mathrm{~S}$ was found. He inherited this mutation from his heterozygous mother (see II-2 in Fig. 1b). In the same family (\# 71) an autistic brother (II-1) did not have this mutation. In the remaining cases, only synonymous nucleotide changes were identified. In particular, mutation c.93C $>\mathrm{T}$ was detected in one patient and mutation c.396G > A was detected in another patient. These four mutations have not been described previously. Finally, the frequency of the alleles of two previously described SNPs (c.453C $>\mathrm{T}$ and c.663C $>\mathrm{T}$ ) [Heidary et al., 1998] were determined in our autistic sample. A summary of all mutations, with their frequencies, of the GRPR gene detected in both patients and control individuals is reported in Table II.

\section{In Silico and In Vitro Analyses}

Our phylogenetic analysis showed that in vertebrates, cysteine at position 6 and leucine at position 181 of the GRPR protein are highly conserved (see Supplementary Fig. 4). In particular, the Leu181 is embedded within the third extracellular domain known to confer binding selectivity [Tokita et al., 2002].

GRP had a high affinity for the hGRPR expressed in BALB/ 3T3 cells (half maximal inhibitory concentration or $\mathrm{IC}_{50}-$ $0.30 \mathrm{nM}$ ), a cell in which the human receptor as well as other Bn receptors have been shown to function in an indistinguishable manner from native receptor cells [Benya et al., 1992, 1994, 1995]. The affinity of GRP for either the pGRPR C6S mutant or the pGRPR_L181 mutant was not significantly different from that for the wild-type GRPR expressed in BALB/3T3 cells (Fig. 2, top panel, Table III). A similar result was seen when the receptors were expressed in COS-7 cells: the wild-type, pGRPR_C6S and pGRPR_L181F mutant receptors all have affinities for GRP in the nanomolar range which were not significantly different (Fig. 2, middle panel, Table III). The wild-type pGRPR caused a 5.4-fold increase in $\left[{ }^{3} \mathrm{H}\right] \mathrm{IP}$ release, with an $\mathrm{EC}_{50}$ (half maximal effective concentration) in the low a

Family A49

I

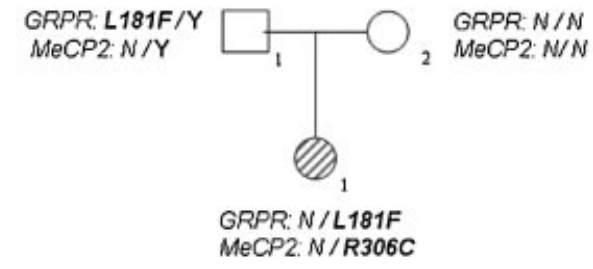

b

Family A71

I

II
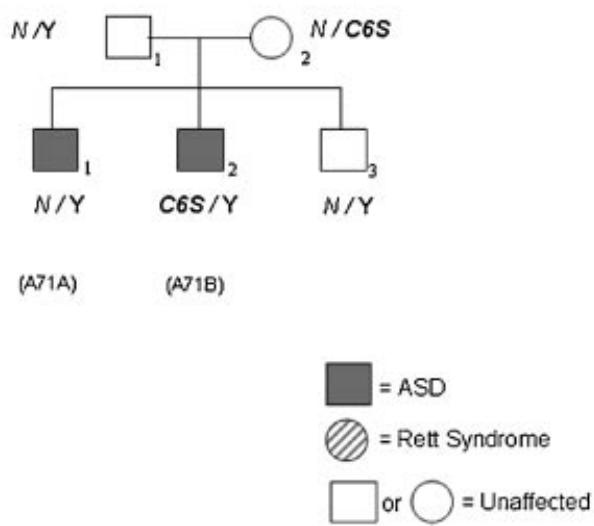

Fig. 1. a: In family \# A49 the daughter affected by Rett syndrome is heterozygous for the MECP2 R306C de novo mutation and has inherited the hGRPR L181F mutation from her father. $\mathrm{N}=$ normal sequence; (b) hGRPR genotypes detected in family \# A71. Mutation C6S is transmitted from the mother to only one (II-2) of the two autistic sibs. The symbol "Y" refers to the Y chromosome.

TABLE II. hGRPR Gene Nucleotide Change and Haplotypes Detected in the Autistic Sicilian Population and Controls

\begin{tabular}{lcc}
\hline & \multicolumn{2}{c}{ No. of X chromosomes $(\%)$} \\
\cline { 2 - 3 } & Autistic $^{\mathrm{a}}$ & Controls $^{\mathrm{b}}$ \\
\hline Nucleotide change $^{\mathrm{c}}$ & & \\
c.17G $>$ C (C6S) & $1 / 165(0.6)$ & $0 / 106(0)$ \\
c.541C $>\mathrm{T}(\mathrm{L} 181 \mathrm{~F})$ & $1 / 165(0.6)$ & $0 / 106(0)$ \\
c.93C $>\mathrm{T}$ (N31N) & $1 / 165(0.6)$ & $0 / 106(0)$ \\
c.396G > A (T132T) & $1 / 165(0.6)$ & $0 / 106(0)$ \\
c.453C $>$ T (S151S)* & $115 / 165(69.7)$ & $79 / 106(74.5)$ \\
c.663C $>$ T (I221I)** & $113 / 165(68.5)$ & $79 / 106(74.5)$ \\
Haplotype*** & & \\
c.453C-c.663C & $50 / 165(30.3)$ & $27 / 106(25.5)$ \\
c.453C-c.663T & $0 / 165(0)$ & $0 / 106(0)$ \\
c.453T-c.663C & $2 / 165(1.2)$ & $0 / 106(0)$ \\
c.453T-c.663T & $113 / 165(68.5)$ & $79 / 106(74.5)$ \\
Total & $165(100 \%)$ & $106(100 \%)$ \\
\hline
\end{tabular}

a 133 males and 16 females.

${ }^{\mathrm{b}} 106$ males.

${ }^{\mathrm{c}}$ Named according to Human Genome Variation Society nomenclature [den Dunnen and Antonarakis, 2000; http://www.hgvs.org/mutnomen].

$* \chi^{2}$ for case-control $=0.522, \mathrm{df}=1, P=0.47$.

$* * \chi^{2}$ for case-control $=0.87, \mathrm{df}=1, P=0.35$.

$* * * \chi^{2}$ for case-control $=1.56 ; \mathrm{df}=2, P=0.46$. 
nanomolar range (i.e., 0.30 nM; Fig. 2, bottom panel, Table III). GRP demonstrated a similar efficacy and potency for stimulating phospholipase $\mathrm{C}$ and increasing $\left[{ }^{3} \mathrm{H}\right] \mathrm{IP}$ production in both the pGRPR_C6S and pGRPR_L181F mutants to that seen in the wild-type receptor (Fig. 2, bottom panel, Table III).

\section{Association Study}

The comparison of the frequency of the two most frequent SNPs c. $453 \mathrm{C}>\mathrm{T}$ and c.663C $>\mathrm{T}$ between "cases" and "controls" did not reveal statistically significant differences ( $P=0.47$ and $P=0.35$, respectively). Of the expected four haplotypes only three were detected in the autistic population

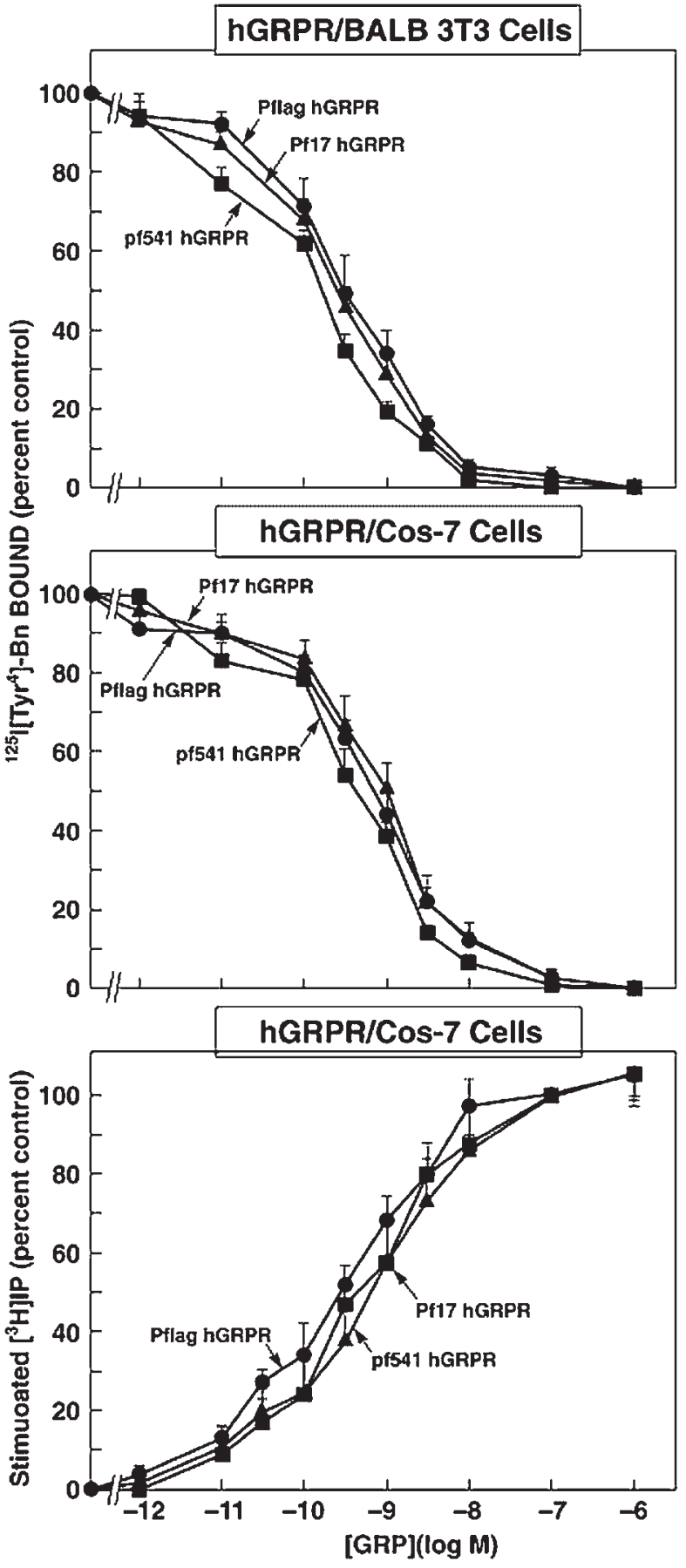

TABLE III. Affinity and Potency of GRP for the Wild-Type GRPR and Two Mutant GRPR's

\begin{tabular}{lcccc}
\hline & \multicolumn{2}{c}{$\begin{array}{c}\text { Binding } \\
\left(\mathrm{IC}_{50}, \mathrm{nM}\right)\end{array}$} & & $\begin{array}{c}\left.{ }^{[3} \mathrm{H}\right] \mathrm{IP} \\
\left(\mathrm{EC}_{50}, \mathrm{nM}\right)\end{array}$ \\
\cline { 2 - 3 } GRPR receptor & $\begin{array}{c}\text { hGRPR/BALB } \\
\text { 3T3 cells }\end{array}$ & $\begin{array}{c}\text { hGRPR/ } \\
\text { COS-7 cells }\end{array}$ & & $\begin{array}{c}\text { hGRPR/ } \\
\text { COS-7 cells }\end{array}$ \\
\hline Wild-type & $0.30 \pm 0.02$ & $0.71 \pm 0.03$ & & $0.30 \pm 0.02$ \\
GRPR C6S & $0.25 \pm 0.01$ & $1.05 \pm 0.06$ & & $0.63 \pm 0.06$ \\
GRPR L181F & $0.16 \pm 0.01$ & $0.42 \pm 0.01$ & & $0.44 \pm 0.03$
\end{tabular}

$\mathrm{IC}_{50}$ and $\mathrm{EC}_{50}$ 's are calculated from the data shown in Figure 2 and are the means of five experiments. All the $P$-values were non-significant (i.e., well above $P<0.05$, in the $P=0.35-0.46$ range).

and two in the general population (see Table II). Also for the two most common haplotypes (C-C and T-T) the difference of their frequency between "cases" and "controls" was not significant $(P=0.46$, see Table II). The two major SNPs haplotypes (C-C and T-T) are different from the most likely ancestral haplotype (T-C) as inferred by the comparison with GRPR gene sequences of other Primates (Pan troglodytes and Macaca mulatta).

\section{DISCUSSION}

The main aim of this study was to contribute new data to assess the actual involvement of GRPR in ASD. To accomplish this we have analyzed the entire coding sequence and intron/ exon splicing junctions of the GRPR gene in a population of 149 patients with ASD. This analysis allowed the identification of four novel point mutations, two of which involve amino acid changes, that is, C6S and $\mathrm{L} 181 \mathrm{~F}$, in the protein sequence of GRPR. The four newly identified alleles are absent in a sample of $106 \mathrm{X}$ chromosomes of unaffected individuals drawn from an ethnically matched control population. The latter population and the autistic population were also typed for two common intragenic polymorphisms previously described by Heidary et al. [1998] to detect the possible occurrence of genetic heterogeneity between the two samples, but no evidence of linkage disequilibrium was found, either for individual alleles or for the corresponding four haplotypes. In family A71, the presence of mutation C6S in only one (II-2 in Fig. 1b) of the two affected brothers suggests that this mutation is not necessary for the expression of ASD in this family.

In family $\mathrm{A} 49$, the presence of mutation $\mathrm{L} 181 \mathrm{~F}$ in the unaffected (hemizygous) father excludes a major effect of this mutation on the phenotype. However, these observations are at least in theory still compatible with a postulated pathogenetic role of $\mathrm{C} 6 \mathrm{~S}$ and/or $\mathrm{L} 181 \mathrm{~F}$ of the hGRPR gene in the A49

Fig. 2. The ability of GRP to inhibit binding and stimulate an increase in $\left[{ }^{3} \mathrm{H}\right] \mathrm{IP}$ at the hGRPR or its mutants transiently expressed in BALB/3T3 cells or COS-7 cells. For binding, Balb 3T3 or COS-7 cells transiently transfected with the hGRPR or its mutants $\left(0.4 \times 10^{6} \mathrm{cell} / \mathrm{ml}\right)$ were incubated for $60 \mathrm{~min}$ at $22^{\circ} \mathrm{C}$ with $50 \mathrm{pM} \mathrm{I}^{125}-\left[\mathrm{DTyr}^{6}, \beta-\mathrm{Ala}^{11}, \mathrm{Phe}^{13}\right.$, $\left.\mathrm{Nle}^{14}\right] \mathrm{Bn}(6-14)$, with or without the indicated concentrations of GRP added. Results are expressed as the percentage of saturable binding without unlabeled peptide added (percent control). To determine changes in $\left[{ }^{3} \mathrm{H}\right] \mathrm{IP}$, COS-7 cell transiently transfected with hGRPR mutants were subcultured and preincubated for $24 \mathrm{hr}$ at $37^{\circ} \mathrm{C}$ with $3 \mathrm{mCi} / \mathrm{ml}$ myo- $\left[2{ }^{3} \mathrm{H}\right]$ inositol. The cells were then incubated with the GRP at the concentrations indicated for 60 min at $37^{\circ} \mathrm{C}$ Values expressed are a percentage of total $\left[{ }^{3} \mathrm{H}\right] \mathrm{IP}$ release stimulated by $1 \mu \mathrm{M}$ Grp. Control and $1 \mu \mathrm{M}$ GRP stimulated values for hGRPR were $1,510 \pm 98$ and $8,200 \pm 210 \mathrm{dpm}$, respectively. Results are the mean \pm SEM from five separate experiments, and in each experiment the data points were determined in duplicate. All the $P$-values were not significant (i.e., well above $P<0.05$, in the $P=0.35-0.46$ range). Pf17 hGRPR cell transfected with pGRPR_C6S, Pf541_hGRPR cell transfected with pGRPR_L181F (see text for addditional details). 
and A71 families. Indeed, the genetic etiology of autism is likely to be multifactorial in nature, that is, each single factor is not a sufficient determinant of the phenotype [Persico and Bourgeron, 2006]. Furthermore, genetic heterogeneity and/or low penetrance may also account for the peculiar pattern of genotype-phenotype relationship observed in the A49 and A71 families.

Mutations C6S and $\mathrm{L} 181 \mathrm{~F}$ affect the first and third extracellular (EC) domains, respectively, of the GRPR and these EC domains are important regions of the receptor because they are involved in selective agonist binding [Tokita et al., 2001]. In particular the EC3 domain seems to be essential for the Grp-ligand specificity [Tokita et al., 2002]. In order to gain some insights on the potential role played by the two amino acid substitutions on GRPR function, we first performed a phylogenetic analysis which revealed that both leucine at position 181 and cysteine at position 6 are strongly conserved in vertebrates. This observation suggests that these two amino acids are potentially important for proper functioning of GRPR. In contrast, the C6S and L181F mutant proteins expressed in COS-7 and BALB/3T3 cells did not affect either the ligand binding or the second messenger production. The signal transduction pathway analyzed in our experiments is postulated to act, through the activated GRPR, by the catalysis of guanine nucleotide exchange on $\mathrm{G} \alpha \mathrm{q}$ to activate phospholipase C-mediated production of inositol 1,4,5-trisphosphate [Exton, 1996]. It is of course difficult to say whether the results of our functional analysis reflect the effect of C6S and L181F mutations on GRPR function in vivo. Studies performed in recent years for example have shown that in addition to eliciting the synthesis of classic second messengers (e.g., DAG and IP3), the activated GRPR is also able to elicit cellular responses using other members of the $\mathrm{Gq}$ family able to transduct the signal along pathways that are different from PLC [Rozengurt, 1998; Fan et al., 2005]. A fully reliable interpretation of the effects of these mutations in vivo is also hampered by the fact that most of our current knowledge on the cellular signaling pathways for GRPR has been built up on information gained by studying cancer and neuroendocrine cell lines, not by studying neural cells.

In summary, our results do not provide support for a major role of the hGRPR gene in ASD in the population of patients we have studied. However, we cannot exclude that this negative outcome was at least in part a consequence of misdiagnosis of a (unknown) number of patients since only two of them were clinically assessed by ADI-R and ADOS-G. On the other hand, we suggest that a full understanding of the potential role of C6S and L181F mutations on GRPR function, and possibly on the pathogenesis of autistic disorder in the A71 and A49 patients should be postponed until we will have a better understanding of the signaling pathways linked to this $G$ protein-coupled receptor, especially in neural cells.

\section{ACKNOWLEDGMENTS}

We wish to thank Dr. Peter Forster (Cambridge, UK) for revising the English style of the manuscript and to acknowledge the expert technical assistance by Pietro Schinocca and Alda Ragalmuto (Troina, Italy).

\section{REFERENCES}

Altschul SF, Madden TL, Schaffer AA, Zhang J, Zhang Z, Miller W, Lipman DJ. 1997. Gapped BLAST and PSI-BLAST: A new generation of protein database search programs. Nucleic Acids Res 25(17):3389-3402.

American Psychiatric Association [APA]. 2000. Diagnostic and Statistical Manual of Mental Disorders-TR, 4th edition. Washington DC: American Psychiatric Press.
Benya RV, Wada E, Battey JF, Fathi Z, Wang LH, Mantey SA, Coy DH, Jensen RT. 1992. Neuromedin B receptors retain functional expression when transfected into BALB 3T3 fibroblasts: Analysis of binding, kinetics, stoichiometry, modulation by guanine nucleotide-binding proteins, and signal transduction and comparison with natively expressed receptors. Mol Pharmacol 42(6):1058-1068.

Benya RV, Fathi Z, Kusui T, Pradhan T, Battey JF, Jensen RT. 1994. Gastrinreleasing peptide receptor-induced internalization, down-regulation, desensitization, and growth: Possible role for cyclic AMP. Mol Pharmacol 46(2):235-245.

Benya RV, Kusui T, Pradhan TK, Battey JF, Jensen RT. 1995. Expression and characterization of cloned human bombesin receptors. Mol Pharmacol 47(1):10-20.

Bienvenu T, Carrie A, de Roux N, Vinet MC, Jonveaux P, Couvert P, Villard L, Arzimanoglou A, Beldjord C, Fontes M, et al. 2000. MECP2 mutations account for most cases of typical forms of Rett syndrome. Hum Mol Genet 9(9):1377-1384.

Brunet O, Lézine I. 1966. Le Développement Psychologique de la Première Enfance, 2nd edition. Paris: Presses Universitaires de France.

Carney RM, Wolpert CM, Ravan SA, Shahbazian M, Ashley-Koch A, Cuccaro ML, Vance JM, Pericak-Vance MA. 2003. Identification of MECP2 mutations in a series of females with autistic disorder. Pediatr Neurol 28(3):205-211.

den Dunnen JT, Antonarakis SE. 2000. Mutation nomenclature extensions and suggestions to describe complex mutations: a discussion. Hum Mutat 15(1):7-12.

Exton JH. 1996. Regulation of phosphoinositide phospholipases by hormones, neurotransmitters, and other agonists linked to $\mathrm{G}$ proteins. Annu Rev Pharmacol Toxicol 36:481-509.

Fan RS, Jacamo RO, Jiang X, Sinnett-Smith J, Rozengurt E. 2005. G proteincoupled receptor activation rapidly stimulates focal adhesion kinase phosphorylation at Ser-843. Mediation by $\mathrm{Ca} 2+$, calmodulin, and $\mathrm{Ca} 2+$ /calmodulin-dependent kinase II. J Biol Chem 280(25):2421224220.

Gillberg C. 1986. Autism and Rett syndrome: Some notes on differential diagnosis. Am J Med Genet 1 (Suppl):127-131.

Griffiths R. 1986. The abilities of babies-revised. London: The Test Agency.

Heidary G, Hampton LL, Schanen NC, Rivkin MJ, Darras BT, Battey J, Francke U. 1998. Exclusion of the gastrin-releasing peptide receptor (GRPR) locus as a candidate gene for Rett syndrome. Am J Med Genet 78(2):173-175.

Ishikawa-Brush Y, Powell JF, Bolton P, Miller AP, Francis F, Willard HF, Lehrach H, Monaco AP. 1997. Autism and multiple exostoses associated with an X;8 translocation occurring within the GRPR gene and $3^{\prime}$ to the SDC2 gene. Hum Mol Genet 6(8):1241-1250.

Karlin S, Altschul SF. 1990. Methods for assessing the statistical significance of molecular sequence features by using general scoring schemes. Proc Natl Acad Sci USA 87(6):2264-2268.

Kates WR, Burnette CP, Eliez S, Strunge LA, Kaplan D, Landa R, Reiss AL, Pearlson GD. 2004. Neuroanatomic variation in monozygotic twin pairs discordant for the narrow phenotype for autism. Am J Psychiatry 161(3):539-546.

Leiter RG. 1979. Leiter International Performance Scale. Chicago: Stoelting.

Lord C, Rutter M, Di Lavore PC, Risi S. 2002. ADOS, Autism Diagnostic Observation Schedule. Western Psychological Services: Los Angeles (Italian version by Tancredi R, Saccani M, Persico AM, Parrini B, Igliozzi $\mathrm{R}$ and Fagioli R. Organizzazioni Speciali: Florence, 2005).

Mantey S, Frucht H, Coy DH, Jensen RT. 1993. Characterization of bombesin receptors using a novel, potent, radiolabeled antagonist that distinguishes bombesin receptor subtypes. Mol Pharmacol 43(5):762774.

Mantey SA, Weber HC, Sainz E, Akeson M, Ryan RR, Pradhan TK, Searles RP, Spindel ER, Battey JF, Coy DH, et al. 1997. Discovery of a high affinity radioligand for the human orphan receptor, bombesin receptor subtype 3, which demonstrates that it has a unique pharmacology compared with other mammalian bombesin receptors. J Biol Chem 272(41):26062-26071.

Marui T, Hashimoto O, Nanba E, Kato C, Tochigi M, Umekage T, Kato N, Sasaki T. 2004. Gastrin-releasing peptide receptor (GRPR) locus in Japanese subjects with autism. Brain Dev 26(1):5-7.

Persico AM, Bourgeron T. 2006. Searching for ways out of the autism maze: Genetic, epigenetic and environmental clues. Trends Neurosci 29(7): $349-358$. 
Roesler R, Henriques JA, Schwartsmann G. 2006. Gastrin-releasing peptide receptor as a molecular target for psychiatric and neurological disorders. CNS Neurol Disord Drug Targets 5(2):197-204.

Romano V, Calì F, Ragalmuto A, D'Anna RP, Flugy A, De Leo G, Giambalvo O, Lisa A, Fiorani O, Di Gaetano C, Salerno A, Tamouza R, Charron D, Zei G, Matullo G, Piazza A. 2003. Autosomal microsatellite and mtDNA genetic analysis in Sicily (Italy). Ann Hum Gen 67:42-53.

Rozengurt E. 1998. V. Gastrointestinal peptide signaling through tyrosine phosphorylation of focal adhesion proteins. Am J Physiol 275(2 Pt 1): G177-G182.

Rutter M, Le Couter A, Lord C. 2003. ADI-R, Autism Diagnostic InterviesRevised. Western Psychological Services: Los Angeles, (Italian version by Faggioli R, Saccani M, Persico AM, Tancredi R, Parrini B and Igliozzi R. Organizzazioni Speciali: Florence, 2005).

Ryan RR, Weber HC, Mantey SA, Hou W, Hilburger ME, Pradhan TK, Coy DH, Jensen RT. 1998. Pharmacology and intracellular signaling mechanisms of the native human orphan receptor BRS-3 in lung cancer cells. J Pharmacol Exp Ther 287(1):366-380.

Schopler E, Dalldorf J. 1980. Autism: Definition, diagnosis, and management. Hosp Pract 15(6):64-73.

Schopler E, Rechler RJ, Bashford A, Lansing MD, Marcus LM. 1990. Individualized assessment and treatment for autistic and developmen- tal disabled children. Vol. I, PsychoEducational Profile Revised (PEP-R). Austin, Texas: Pro-ed.

Schumann M, Nakagawa T, Mantey SA, Tokita K, Venzon DJ, Hocart SJ, Benya RV, Jensen RT. 2003. Importance of amino acids of the central portion of the second intracellular loop of the gastrin-releasing Peptide receptor for phospholipase $\mathrm{C}$ activation, internalization, and chronic down-regulation. J Pharmacol Exp Ther 307(2):597-607.

Shumyatsky GP, Tsvetkov E, Malleret G, Vronskaya S, Hatton M, Hampton L, Battey JF, Dulac C, Kandel ER, Bolshakov VY. 2002. Identification of a signaling network in lateral nucleus of amygdala important for inhibiting memory specifically related to learned fear. Cell 111(6):905-918.

Sparrow SS, Balla D, Cicchetti D. 1984. Vineland Adaptive Behavior Scales (Survey Form). Circle Pines, MN: American Guidance Service.

Tokita K, Katsuno T, Hocart SJ, Coy DH, Llinares M, Martinez J, Jensen RT. 2001. Molecular basis for selectivity of high affinity peptide antagonists for the gastrin-releasing peptide receptor. J Biol Chem 276(39):3665236663 .

Tokita K, Hocart SJ, Coy DH, Jensen RT. 2002. Molecular basis of the selectivity of gastrin-releasing peptide receptor for gastrin-releasing peptide. Mol Pharmacol 61(6):1435-1443.

Wechsler D. 1974. Wechsler Intelligence Scale for Children-Revised. New York: The Pyschological Corporation. 